\title{
相対性理論の進展の概略
}

\section{A Brief Outline of the Development of the Theory of Relativity}

\section{筆 者 A. Einstein 教授}

（英訳 Robert W. Lawson 博士）

一連の考え方の進展を、できるだけ簡潔な形で、なお かつ発展の連続性を完全に保ちながら俯瞰するというの は、どこか抗し難い魅力がある。私たちはそれを、相対 性理論について試み、すべての進歩は、小さな、ほとん ど自明な思考の積み重ねからなっていることを明らかに したい。

発展の全貌はファラデーとマクスウェルの考えに端を 発し、その影響は最後までおよぶ。すなわち、あらゆる 物理過程は（遠隔作用ではなく）近接作用によるのであ り、数学的に言えば、偏微分方程式で表わされる。マク スウェルはこれを、真空の変位電流の磁気効果の概念、 ならびに、誘導により生じた電気力学場と静電場の性質 が同一であるとの仮定に基づいて、静止物体の電磁過程 に適用することに成功した。

電気力学の動く物体への拡張は、マクスウェルの大勢 の後継者たちの肩にかかることとなった。H. ヘルツは、 重さのある物体とよく似た物理的特性を空っぽの空間 (エーテル) に与えることにより、この問題の解決を試 みた。とりわけ、エーテルは重みのある物体と同じよう に、どの点においても決まった速度をもつにちがいない、 と。静止物体のように、電磁気あるいは磁電気の誘導は、 それぞれ、電気または磁気の流量変化率によって決まる。 ただし、そのような変化の速度は物体と共に動く面積要 素について語られているのだという条件付きで。しかし、 ヘルツの理論は、流れる液体中を伝搬する光について のフィゾーの基礎的な実験に反することとなる。マクス ウェル理論の、最も明白と思われた動く物体の場合への 拡張は、実験の諸結果とは矛盾してしまったのである。

この時点で、H. A. ローレンツが救いの手を差し伸べ
た。物質の原子論に絶対の信頼をおいていたローレンツ は、原子を、連続的な電磁場の座とみなすことなどで きないと感じた。彼は、電磁場は、連続的と思われてい たエーテルの条件ではないだろうかと考えた。ローレン ツは、力学的および物理学的な観点の両面から、エーテ ルは本質的に物質とは無関係だと考えていた。つまり、 エーテルは物質の運動に関与しておらず、エーテルと物 質の相互関係が想定されるのは、物質が、付着する電荷 の運び手とみなされる場合だけだと考えていた。ローレ ンツの理論の大きな価值は、静止物体と動く物体の電気 力学全体が、空っぽの空間におけるマクスウェルの方程 式に帰せられるという事実にある。この理論は、方法論 から見てもへルツの理論を凌ぐだけでなく、H. A. ロー レンツはまた、理論の助けを借りて見事に実験事実の説 明に成功したのだ。

この理論は、根本的に重要なある一点においてのみ、 不充分なように思われる。どうやら、動いている他のす べての座標系と比べて、特殊な運動状態（エーテルに対 して静止状態）にある、一つの座標系だけを優先させて いるようなのだ。この点で、この理論は古典力学と真つ 向から対立しているように思われる。古典力学では、互 いに一様に動いているすべての慣性系は、同等な座標 系として認められている（特殊相対性原理）。ちなみに、 電気力学の領域におけるあらゆる経験（特にマイケルソ ンの実験）も、あらゆる慣性系が同等であるという考え を裏付けるもので、特殊相対性原理を支持している。

特殊相対性理論は、その根本的な性質のために容認で きないと思われてしまう困難さのお陰で生まれた。この 理論は、次の疑問に対する答えから始まる：特殊相対性 
原理は、本当に、空っぽの空間におけるマクスウェルの 場の理論と矛盾するのだろうか？この疑問に対する答 えは、イエスであるかのように見える。なぜならば、方 程式が一つの座標系 Kで成り立つとして、もし、どこ から見ても容易に立証できる変換方程式と一致する新し い座標系 $K^{\prime}$ を導入すれば、マクスウェルの方程式は、新 しい座標 $\left(x^{\prime}, y^{\prime}, z^{\prime}, t^{\prime}\right)$ ではもはや成り立たなくなるか らだ。

$$
\left.\begin{array}{l}
x^{\prime}=x-v t \\
y^{\prime}=y \\
z^{\prime}=z \\
t^{\prime}=t
\end{array}\right\} \quad\{\text { ガリレオ変換 }\}
$$

しかし、見かけに騙されてはならない。時空の物理的な 重要性についてさらに綿密な分析が行なわれるにしたが つて、ガリレオ変換があいまいな仮定の上に成り立って いることが明らかになったのだ。特に、何かが同時であ るということは、使われた座標系の運動状態から独立し て意味をもつ、と仮定されている。真空の場の方程式は、 次のような変換式を使用すると、特殊相対性原理を満た すことがわかった。

$$
\left.\begin{array}{l}
x^{\prime}=\frac{x-v t}{\sqrt{I-v^{2} / c^{2}}} \\
y^{\prime}=y \\
z^{\prime}=z \\
t^{\prime}=\frac{t-v x / c^{2}}{\sqrt{I-v^{2} / c^{2}}}
\end{array}\right\} \quad\{\text { ローレンツ変換 }\}
$$

この方程式で、 $x, y, z$ は、座標系に対して静止した物差 しで測った座標を表している。そして、 $t$ は、静止状態 にある、調整済みの同じ造りの時計で測った時間を示し ている。

ところで、特殊相対性原理が成り立つためには、物理 学のあらゆる方程式が、一つの慣性系から別の慣性系へ の変換に際して、その恰好を変えない必要がある。その 際、その変化を計算するためにローレンツ変換が利用さ れる。数学の言葉を使うのであれば、物理法則をあらわ すあらゆる方程式は、ローレンツ変換に関して共変的で なければならない。というわけで、方法面から見るかぎ り、特殊相対性原理は、第二種の永久運動の不可能性に 関するカルノーの原理に匹敵する。なぜならば、後者（カ ルノーの理論）の上うに、特殊相対性原理はあらゅる自 然法則が満たすべき一般条件を私たちに与えてくれるか らだ。

後に、H.ミンコフスキーが、この共変条件について、き わめて優美で示唆に富む表式を発見した。それは、三次 元のユークリッド幾何学と物理学の時空連続体の形式的 な関連をあらわにしている。

このことから、物理学の方程式での役割からすれば、 物理学的な意味合いは別として、時間は空間座標と同等 だといえる（実数との関係は別だが）。この観点から、物 理学はいわば四次元のユークリッド幾何学、いや、もつ と正確には四次元のユークリッド連続体の静力学なので ある。

特殊相対性理論は、二つの主な段階を経てつくられる。 一つは、時空の「計り方」をマクスウェル電気力学に合 わせる作業であり、もう一つは、変更された時空の「計 
り方」に他分野の物理学を合わせる作業である。初めの 過程からは、同時刻の相対性、運動が測定用の物差しと 時計へ与える影響、運動学の修正、そして特に、速度の 新しい加法定理が出てくる。第二の過程からは、速度が 大きい場合のニュートンの運動法則の修正、ならびに、 慣性質量の性質についての基本的に重要な情報がもたら される。

慣性は、物質の基本的な性質ではない。実際、より基 本的な属性に遡ることのできない量ではなく、エネル ギーの一つの性質にすぎないことがわかつた。もし、 $\mathrm{E}$ というエネルギー量が、ある物体に与えられるとすれば、 その物体の慣性質量は、 $\mathrm{E} / c^{2}$ の大きさだけ増大する。こ こで、 $c$ は真空中の光速である。一方、質量 $m$ の物体は、 $m c^{2}$ という量のエネルギーの貯蔵庫と考えられる。

やがて、自然なやり方で重力の科学を特殊相対性理論
と結びつけるのは不可能であることがわかつた。これに 関して、私は重力には基本的な性質があり、それが重力 を電磁力と区別している事実に気づいて、驚きを隠せな かった。あらゆる物体は、重力場のなかで同じ加速度で 落下する。あるいは、同じ事実の別の言い方にすぎない が、ある物体の重力質量と慣性質量は互いに数值的に等 しい。この数值的な等しさから、その性質も同じであ ることが予想される。重力と慣性は同じものなのだろう か？この疑問が、直接、一般相対性理論へとつながる。 たとえば、地球に対して静止しているあらゆる物体に作 用する遠心力を、「実在」する重力場か、そうした場の 一部だとみなせば、地球は回転していない、と考えるこ とはできないだろうか？もし、この考えが実行できれ ば、本当に重力と慣性の同一性を立証できるだろう。な ぜならば、回転に関与しない系から見て慣性とみなされ

\section{三次元のユークリッド幾何学}

空間の隣接した 2 点に対応して、尺度となる数值(距 離 $d s)$ がある。それは、次の式である。

$$
d s^{2}=d x_{1}^{2}+d x_{2}^{2}+d x_{3}^{2}
$$

それは、選ばれた座標系と無関係で、単位長さの物 差しを使って測ることができる。

許される変換は、 $d s^{2}$ の表式を不変に保つ。すなわ ち、線形直交変換が許される。

そのような変換により、ユークリッド幾何学の法則 は不変である。

\section{特殊相対性理論}

時空の隣接した 2 点（点事象）に対応して、尺度 となる数值(距離 $d s$ )がある。それは、次の式である。 $d s^{2}=d x_{1}{ }^{2}+d x_{2}{ }^{2}+d x_{3}{ }^{2}+d x_{4}{ }^{2}$

それは、選ばれた慣性系と無関係で、単位長さの物 差しと標準時計で測られる。 $x_{1}, x_{2}, x_{3}$ は、ここで は直交座標で、一方、 $x_{4}=\sqrt{-\mathrm{I}} c t$ は、時間に虚数単 位と光速を掛けたもの。

許される変換は、 $d s^{2}$ の表式を不変に保つ。すなわち、 $x_{1}, x_{2}, x_{3}, x_{4}$ の実数性が保たれるような線形直交な置 き換えが許される。そのような置き換えがローレン ツ変換である。

そのような変換により、物理学の法則は不変である。 
る性質が、回転に係わる系との関係では重力と解釈でき るからだ。ニュートンによ机ば、こうした解釈は不可能 である。ニュートンの法則では、遠心力の場が物質に よって創られるとは考えられず、またニュートンの理論 では、「コリオリ場」の型の「実在」する場は許されない からだ。しかし、もしかしたらニュートンの場の理論は、 「回転」座標系を含む場に適合する、別の理論に置き換 えられるのではないか？慣性と重力の質量が同じもの だという私の信念は、心の中で、この解釈は正しいのだ という、絶対的な確信の感触にまで高まった。この点に ついて私は、次のような考元に刺激された。私たちは「み かけ」の場をよく知っているが、そ机は、慣性系に対し て任意の運動をしている座標系において成り立つ。その ような特殊な場の助けを借りて私たちは、重力場がすべ からく満たすべき法則を研究できるにちがいない。この 点について、私たちは、量られる質量が、場を創る決 定因数になるか、あるいは、特殊相対性理論の基本的 な結果によるのであ机ば、エネルギー密度（テンソルの 変換性をもつ量）が場をつくるという事実を考慮すべき だろう。

他方では、特殊相対性理論の計量的な結果に基づく考 察から、ユークリッド計量は加速された座標系に関して はもはや妥当ではありえないという結論に至る。このこ とが理論の進歩を数年も滞らせたのであるが、ユークリ ッド計量が、小さい領域にしかあてはまらないのだとい うことがわかって、この大いなる困難は解消された。結 果として、これまで特殊相対性理論で物理学的に定義さ れてきた大きさdsは、一般相対性理論においても、そ の重要性を保ち続けることとなった。しかし、座標その ものは、もはや直接的な重要性を失い、物理学的な意味 合いを持たない、時空の点を数えるだけが目的の単なる 数值へと成り下がつた。つまり、一般相対性理論では、 座標は、表面の理論におけるガウスの座標と同じ機能を 果たしている。以上に述べたことから、こうした一般的 な座標では、測定できる量のds は次の形式で表示でき なければならない。

$$
d s^{2}=\sum_{u v} g_{u v} d x_{u} d x_{v}
$$

ここで、記号 $g_{u v}$ は、時空座標の関数である。上記の ことから、また、因数 $g_{u v}$ は一方では時空の計量を決定し、 他方では質点の力学的なふるまいを司る重力場を決定す ることがわかる。

重力場の法則は、主に次の条件から決定される：第一 に、それは、座標系の選び方によらず成り立たなければ ならない。第二に、それは、物質のエネルギー・テンソ ルにより決定され齐ばならない。第三に、それは、二階 より高い因数 $g_{u v}$ の微分係数を含んではならず、線形で なければならない。このようにして、一つの法則が得ら れる。そ机は、ニュートンの法則と基本的には異なるも のの、それから導かれた近似が後者に正確に対応してい るので、その理論が、実験で明白に検証できそうな基準 は、数えるほどしか存在しない。

次にあげるのが、今のところ解決が待ち望まれる、重 要な疑問のいくつかである。電気と重力の場は、本当に 性質が違いすぎて、両者を帰着させることのできる形式 的な単位など存在しないのか？ 重力場は、物体の構成 に関与しているのか、そして、原子核内の連続体は、認 めうるほどに非ユークリッドなのか？ 最後の疑問は、 宇宙論の問題に関係している。慣性は、遠くの質量との 相互作用まで追跡されるべきか？そして、これに関連 して：宇宙の空間的な広がりは有限なのか？ 私の見解 がエデイントンと異なるのは、まさにこの点なのだ。マッ 八と同様、肯定的な答えが避けがたいと私は感じている が、当面の間、何も証明されないだろう。大規模な恒星 系の力学的な研究が、宇宙の広大な領域に対するニュー トンの重力法則の妥当性の限界の観点から実施される まで、最終的に、この魅惑的な疑問の数々を解決する ための確固たる基盤を得ることは、抏そらく不可能だ ろう。

※ (原文は 1921 年の Nature vol.106 に揭載された $)$ 